\title{
KULTURA

\section{JAK UŁOŻYĆ PUZZLE? \\ BADANIA NAD KULTURĄ WĘGIERSKICH ROBOTNIKÓW Z POŁOWY LAT SIEDEMDZIESIĄTYCH XX WIEKU I KILKA ZAGADNIEŃ EPISTEMOLOGICZNYCH}

W ciągu pięciu lat od czasu powstania w roku 2009 Archiwum Głosów $\mathrm{XX}$ wieku pracowało $\mathrm{w}$ pogłębiony sposób $\mathrm{z}$ kilkunastoma zbiorami danych ${ }^{1}$. $\mathrm{W}$ wielu przypadkach próbowano zaprowadzić porządek w chaosie. Uratowanych zostało mnóstwo pudeł zawierających materiały badawcze dawnych pracowników naukowych, które omal nie zostały wyrzucone podczas sprzątania towarzyszącego przeprowadzce Instytutu. Wśród ocalonych znalazł się zbiór dokumentujący styl życia robotników $z$ lat siedemdziesiątych $\mathrm{XX}$ wieku. Te nieuporządkowane pudła były przechowywane w pustym pomieszczeniu. Pracownicy Archiwum mieli nadzieję na zebranie wszystkich fragmentów puzzli

Adres do korespondencji: gardos.judit@tk.mta.hu

1 The Voices of the 20 $0^{\text {th }}$ Century Archive and Research Group (Instytut Socjologii, Centrum Nauk Społecznych Węgierskiej Akademii Nauk) to socjologiczne archiwum danych jakościowych i skupiona wokół niego grupa badaczy, pracująca w Budapeszcie. Przechowuje kolekcje badań jakościowych prowadzonych od lat siedemdziesiątych XX wieku aż po czasy współczesne. Dotyczą one wielu tematów, takich jak przedsiębiorcy nad Balatonem, prostytucja, funkcjonariusze, historia węgierskiej socjologii, opieka zdrowotna, rodzina, styl życia, klasa wyższa, klasa średnia, bezdomność, rodzina, przeszkody w adaptacji, praca, holokaust Romów, integracja społeczna, styl życia robotników, mobilność, narodowa kultura życia domowego, komunikacja masowa, inteligencja, kreatywność muzyczna, alternatywne strategie życiowe, ruchy walki o prawa obywatelskie Romów, wspomnienia o Holokauście lub pracy przymusowej podczas drugiej wojny światowej. Archiwum przechowuje obecnie około 10000 dokumentów elektronicznych i stale się powiększa.

The Voices of the 20 th Century Archive and Research Group jest obecnie finansowane przez Węgierski Narodowy Fundusz Badań Naukowych (OTKA), grant numer 101046 (www.voicesofthe20century.hu). 
i ułożenie z nich spójnej całości, która po trudnej i mozolnej pracy archiwalnej okaże się piękną, kompletną kolekcją.

Uważano $^{2}$, że zbiór bazuje na badaniach prowadzonych $\mathrm{w}$ ramach projektu pewnej węgierskiej socjolog pracującej wówczas w Instytucie Socjologii. Badania zostały nawet zaprezentowane pod jej nazwiskiem podczas konferencji. Zapanowała wówczas konsternacja, gdyż pani socjolog wstała $z$ sali i dość emocjonalnie oświadczyła, że nie ma nic wspólnego z tą kolekcją i nie była osobą prowadzącą badania. Okazało się, że fragment puzzli dotyczący kierownika projektu został błędnie odczytany i że wciąż go brakuje.

Kolejnym poszukiwanym elementem układanki był historyczny kontekst badań. Zapoznano się z literaturą naukową i studiowano nieopracowany materiał ${ }^{3}$. Niektórzy dawni pracownicy Instytutu Socjologii pomogli określić fragmenty badań, z innymi udało się nawet przeprowadzić wywiady. Wówczas zidentyfikowano kolejny fragment puzzli - okazało się, że materiały dotyczące stylu życia robotników należą do serii tematycznie powiązanych projektów badawczych poświęconych klasie robotniczej w latach siedemdziesiątych. Badanie, którego efektem był ten konkretny zbiór, zostało zrealizowane między rokiem 1972 a 1975. Niestety, wspomnienia osób, z którymi przeprowadzono rozmowy, były mało konkretne i wciąż nieukończone badania nad kontekstem historycznym nie zawsze są rozstrzygające. Jaka była chronologia projektów badawczych? Kto i w jakim stopniu zlecił i kontrolował badania? Fragment puzzli dotyczący kontekstu naukowego nie jest do końca klarowny.

Zbiór w Archiwum obejmuje około 430 dokumentów. To całkiem dużo, ale odkryto, że jedynie jedna trzecia $z$ nich zawiera nieprzetworzone dane. Ponieważ wywiady przeprowadzono z około 1200 osobami, oznacza to, że $90 \%$ dokumentów zaginęło. Alíz Mátyus, który brał udział w badaniu, utrzymuje, że w latach dziewięćdziesiątych większość dokumentacji została posortowana i wyrzucona ${ }^{4}$. Dane zbierano w przybliżeniu w dziesięciu węgierskich fabrykach. Dokumentacja dotyczyła każdego z respondentów. Składały się na nią cztery różne teksty: często bardzo długi wywiad o życiu codziennym, abstrakt wywiadu, kwestionariusz oraz analiza porównawcza zawartości wywiadu i kwestionariusza. Uważa się, że wszystkie cztery typy dokumentów były dostępne $\mathrm{w}$ trakcie prowadzenia oryginalnych badań, ale nie można mieć pewności. Obecnie kolekcja postrzegana jest jako niekompletna, ponieważ oprócz zaginionych pełnych akt, w około $50 \%$ przypadków brakuje dokumentów jednego typu lub więcej.

\footnotetext{
2 Informacja pochodzi od jednego $z$ badaczy pracujących w Instytucie od lat siedemdziesiątych $\mathrm{XX}$ wieku.

3 Jest pewne, że zdecydowana większość materiałów od momentu powstania nie była analizowana.

${ }^{4}$ Zob. wywiad w Archiwum Głosów XX wieku (w trakcie publikacji).
} 
Udało się zidentyfikować kilka publikacji opartych na tych badaniach (zob. np. Vidovszky 1983), ale jest to niewiele w porównaniu z olbrzymią ilością oryginalnego materiału badawczego. Obszerne badania $w$ archiwach mogłyby wykazać, w jaki sposób pierwotny materiał badawczy można powiązać z (nie zawsze dostępnymi publicznie) odkryciami naukowymi, kontekstem badań itd. Niestety, z powodu gruntownych zmian struktur badawczych, reorganizacji instytutów i zmian politycznych wiele materiałów zaginęło lub niemożliwe jest ich odzyskanie ${ }^{5}$. Elementy tej układanki prawdopodobnie zaginęły na zawsze. Teraz można jedynie spekulować, dlaczego powstało tak mało publikacji opartych na tych materiałach.

Badania zostały przeprowadzone w Węgierskiej Akademii Nauk, przez Centrum Socjologii, Instytut Kultury, który istniał od lat siedemdziesiątych do dziewięćdziesiątych XX wieku. Była to właściwie seria badań na podobne tematy (na przykład kultura robotnicza, styl życia) zrealizowanych przez małe grupy czołowych badaczy Centrum. Centrum Socjologii skupiało naukowców o różnych poglądach politycznych (również z opozycji) i przez niektórych badaczy było postrzegane jako miejsce chronione ${ }^{6}$. Jest to tym bardziej istotne, $\dot{z}$ e w połowie lat siedemdziesiątych w polityce węgierskiej można było zaobserwować zwrot w kierunku konserwatyzmu, wpływający również na nauki społeczne: jedni ważni naukowcy (Márkus, Heller i in.) tracili pracę, a inni (Szelényi, Konrád) zostali aresztowani (Szabari 2005).

Archiwum nie dysponuje (jeszcze?) żadnymi ówczesnymi planami badawczymi ani konkretną informacją na piśmie dotyczącą kontekstu, w którym badania były realizowane. W latach siedemdziesiątych zostały przeprowadzone rozległe, interdyscyplinarne badania dotyczące klasy robotniczej, koordynowane przez Instytut Nauk Społecznych, ulokowany przy Centralnym Komitecie rządzącej na Węgrzech Węgierskiej Socjalistycznej Partii Robotniczej. Materiały dotyczące kontekstu rozpoczęcia badań i inne powiązane ważne dokumenty archiwalne mogą znajdować się w kilku miejscach: w archiwum dawnego Instytutu Kultury, które miało być zamknięte 7 , we wciąż nieodnalezionych pudłach w Instytucie Socjologii lub w siedzibie Węgierskiej Socjalistycznej Partii Robotniczej.

Badania nad stylem życia w latach siedemdziesiątych obejmowały jakościowe i ilościowe analizy tego, jak dużo czasu i w jaki sposób Węgrzy poświę-

${ }^{5}$ Zob. wywiad z Aliz Mátyus w Archiwum Głosy XX wieku (w trakcie publikacji).

${ }^{6} \mathrm{O}$ Instytutcie zob. wywiad z Ágnes i Gábor Kapitány w the Voices of the $20^{\text {th }}$ Century Archive (http://www.20szazadhangja.hu/kapitany_agnes_es_kapitany_gabor). Podobne podsumowanie przedstawiła Timea Tibori, emerytowana badaczka z Centrum Nauk Społecznych.

7 W marcu 2014 roku. 
cają na pracę i odpoczynek. Analiza „budżetów czasu” została wprowadzona do węgierskiej i międzynarodowej socjologii przez Alexandra Szalai (w tamtym okresie np. Szalai 1972), metodę tę zastosowano również w badaniach nad zagadnieniem stosunku czasu pracy do odpoczynku.

Badania te na Węgrzech (i być może w innych krajach Europy Wschodniej) w latach siedemdziesiątych i osiemdziesiątych były nie tylko opisowym studium, przeprowadzonym w celach czysto poznawczych. Był to bardzo modny temat, na który nie szczędzono środków i który stanowił ideologicznie ugruntowane zagadnienie badawcze. Wiele znaczących badań i uwag zostało poświęconych problematyce kultury i stylu życia. Do najważniejszych zaliczane są prace Ágnes Losonczi. Wiele $z$ nich przeprowadzono $z$ wykorzystaniem metod jakościowych, wywiadów, zdjęć, obserwacji antropologicznej. Inne ważne problemy w tamtym czasie to stratyfikacja społeczna i mobilność. Ten uznany przez ideologię marksistowską temat dał możliwość badania węgierskiej rzeczywistości społecznej. Kolejny problem podjęty w latach siedemdziesiątych to sytuacja mniejszości romskiej na Węgrzech ${ }^{8}$.

„Kultura marksistowska” była postrzegana przez naukowców prowadzących w tamtym czasie badania nad stylem życia jako cel możliwy do osiągnięcia poprzez „socjalistyczny sposób bycia” (Szántó 1967, 1979). Jedną z zasadniczych kwestii stanowiła, rozpatrywana w świetle teorii generatywności Noama Chomskiego, kreatywność robotników: ich zdolność do tworzenia muzyki i literatury. Istotne pytanie dotyczyło tego, w jaki sposób kreatywność i kreatywne aktywności wpasowują się w życie codzienne różnych ludzi zatrudnionych w fabryce. Było to postrzegane jako wyznacznik demokratyzacji społeczeństwa węgierskiego.

Powody, dla których te badania są uważane za ważne, zostały wskazane przez głównego badacza tego obszaru Miklósa Szántó (1980). Twierdził on, że państwo musi organizować życie codzienne ludzi i dlatego trzeba prowadzić badania nad obowiązującymi wzorami życia codziennego. Powinna bowiem istnieć wiedza odpowiadająca na pytanie, czy demokratyzacja, która była głównym celem systemu socjalistycznego, już nastąpiła. Jednym z kluczowych zagadnień było sprawdzanie, czy to system kapitalistyczny, czy socjalistyczny zapewnia lepszy standard życia; musiały pojawić się badania wskazujące, który z nich lepiej pod tym względem się sprawdza. Oczywiście istniał oficjalny nacisk, aby idealizować obraz sytuacji i pomniejszać wady. Powody prowadzenia takich badań były oczywiście ideologiczne. Szántó (1967) podaje również kilka powodów naukowych: styl życia nie może być analizowany jedynie poprzez badania „budżetów czasu”, tak popularnych w tamtym czasie. Funkcja sztuki, literatury, nauki w codziennym życiu i powody indywidualnych preferencji stały się zatem

8 Zwięzłe wprowadzenie Very Szabari (2005) do historii węgierskiej socjologii w czasach socjalistycznych jest dostępne w języku czeskim. Niestety, historia socjologii na Węgrzech w XX wieku jest polem niezbadanym, pracuje nad nim jedynie kilka osób. 
przedmiotem zainteresowania; starano się uzyskać dane dotyczące powiązań między stylem życia a wzorami zachowania. Oprócz badaczy z dziedziny nauk społecznych mocno zaangażowani w rozwiązywanie tego zagadnienia byli również filozofowie. Co za tym idzie, w dalszej perspektywie włączyli się oni również w badania nad wpływem przekonań marksistowskich na życie codzienne.

Publikacją do pewnego stopnia opartą na niewielkiej części omawianych materiałów badawczych jest książka o zależnościach między przyzwyczajeniami związanymi ze spędzaniem wolnego czasu a cechami osobowości. Z tekstu naukowego opartego na tym materiale wyłania się wyraźnie przekonanie, że spędzanie czasu na słuchaniu muzyki bigbitowej czy z przyjaciółmi lub poświęcanie go na hobby rekreacyjne, takie jak ogrodnictwo lub robótki ręczne, nie jest postrzegane jako uczestnictwo w kulturze (Vidovszky 1983). Dobrze widziane, jeśli chodzi o zajęcia w wolnym czasie, było celowe podnoszenie swoich kwalifikacji (Vidovszky 1983, s. 18); można zauważyć, że kultura wysoka jest faworyzowana i postrzegana jako właściwy sposób uczestnictwa w kulturze. Badacze podjęli próbę zmierzenia postaw na podstawie kwestionariusza; rezultaty zanotowano osobno na każdym z kwestionariuszy. Zmierzona została konsumpcja różnych dóbr kulturalnych; brano pod uwagę zarówno bezpłatne (telewizja, radio...), jak i płatne aktywności (teatr, kino...). Na podstawie tych pomiarów przeprowadzano ocenę postawy, czyli wyznaczano stopień „kulturyzacji" (uczestnictwa w kulturze) każdego ankietowanego. Współczynnik ten oparty jest na konsumpcji przede wszystkim dóbr kultury wysokiej. Indeks obejmuje: teatr: min. 1 raz/rok; wystawa: min. 1 raz/rok; koncert muzyki klasycznej: min. $1 \mathrm{raz} / \mathrm{rok}$; czytanie książek: min. $1 \mathrm{raz} /$ miesiąc; edukacja dla dorosłych: uczestniczył/a; sztuka amatorska: uczestniczył/a; kino artystyczne: silne zainteresowanie.

Konsumpcja i produkcja dóbr kultury wysokiej jest jedną z cech, które w tym typie badań podejmowanych ze względów politycznych oceniano wysoko. Druga to zaangażowanie w sprawy społeczności lokalnej lub społeczeństwa ogółem. Teksty oparte na tym badaniu w wielu przypadkach dotyczą istoty osobistego podejścia do społeczności jako takiej.

Oprócz kwestionariusza jako metodę badawczą stosowano również wywiady, poświęcone życiu codziennemu, pracy, rodzinie i wypoczynkowi. Mają one bardzo szeroki zakres, pozwalają uzyskać również dane dotyczące historii życia. Wydaje się, że w materiale pierwotnym pytania i komentarze polityczne czy ideologiczne nie występują ${ }^{9}$. Oczywiście, materiał jest bardzo różnej jakości, w zależności od respondenta oraz, oczywiście, od prowadzącego wywiad. Niektóre wywiady mają po sto-dwieście stron, inne są dużo krótsze. Obejmują bardzo różnorodne tematy: obiektywne dane, ale również tak zwane „subiektywne uczucia"10; dotyczą wychowania, rodziców, szkoły, życia codziennego,

9 Wspomniany tutaj materiał badawczy nie został jeszcze dokładanie przeanalizowany.

10 Zob. wytyczne do wywiadu dostępne w Archiwum. 
pracy i czasu wolnego itd. Wywiady pogłębione skupiają się również na temacie szczęścia, jego relacji do pracy i wypoczynku oraz najważniejszych wartości w życiu.

Znamy już więc wiele fragmentów układanki, lecz wielu wciąż brakuje. Jeśli chcemy ustalić, czy ponowne wykorzystanie badań jest epistemologicznie uzasadnione, musimy zdawać sobie sprawę, że w przypadku danych sprzed czterdziestu lat, nawet jeśli osoby zaangażowane w te badania w latach siedemdziesiątych wciąż żyją, nie możemy liczyć na informacje od nich. Doświadczenie pokazuje, że często nie pamiętają dokładnych okoliczności, a nawet chronologii badań. Wielu jest niedostępnych: nie żyją, są zajęci lub po prostu nie życzą sobie rozmowy. Możemy stwierdzić jedynie fakt, że w materiałach ślad zostawiło wiele danych kontekstualnych i metadanych, których nie mamy teraz, ale na pewno były dostępne badaczom prowadzącym badania. Obecnie obraz tej niekompletnej całości jest więc inny, a my nie mamy możliwości, aby dopełnić tę badawczą układankę z lat siedemdziesiątych XX wieku, nawet gdybyśmy chcieli.

Ponieważ współcześni naukowcy nie posiadają wielu informacji, które mogły wpływać na analizę materiałów w latach siedemdziesiątych, wówczas gdy były zbierane, trudno określić analizę nieprzetworzonych materiałów po czterdziestu latach jako „pierwotną”. Nierozsądna zatem może okazać się wiara w to, że ktokolwiek może dysponować właściwymi dla danych czasów informacjami potrzebnymi do analizy takiego materiału. Każda analiza jest interpretacją wynikającą z bardzo specyficznej, osobistej wiedzy badacza, uwarunkowanej między innymi tradycją naukową, znajomością literatury naukowej, własnym doświadczeniem zawodowym i doświadczeniem zebranym w terenie. Nie tylko nie możemy zobaczyć kompletnej układanki z lat siedemdziesiątych, ale też za każdym razem obecnie analizując dane tworzymy nową układankę.

Członkowie zespołu Natashy Mauthner ponownie spojrzeli na trzy przeprowadzone przez siebie badania i wróciwszy do nich odkryli, że sens danych badawczych leży nie w samych tych danych, ale jest im nadawany przez tych, którzy je opisują, pozostaje pod dużym wpływem kontekstu teoretycznego, $\mathrm{w}$ jakim one powstają i są interpretowane. Twierdzą oni, że epistemologia refleksyjna i interpretacyjna nie uzasadnia powtórnej analizy danych, oprócz badań historycznych i metodologicznych (Mauthner i in. 1998, s. 743). Może zatem nie powinniśmy wykorzystywać zachowanych badań dotyczących stylu życia robotników w latach siedemdziesiątych XX wieku w celu uzyskania nowej wiedzy o ówczesnym społeczeństwie?

Martyn Hammersley (1997, s. 135) zwraca uwagę, że nie można przeprowadzić prawdziwie transparentnych badan, nawet dysponując surowym materiałem badawczym. Niamh Moore (2007, s. 3.3.) zaś zauważa, że teza 
Mauthner, iż jedynie pierwotni badacze mogą poprawnie interpretować dane, wnikając w istotę projektu badawczego (Mauthner in. 1998), opiera się także na założeniu realizmu badawczego, który w innych miejscach autorka przecież kwestionuje.

Zgadzając się z twierdzeniem Niamh Moore, że nie ma istotnej różnicy między badaniami tak zwanymi pierwotnymi a wtórnymi, można uznać, iż dane, które uzyskali pierwotni badacze, kontekstualnie i tekstualnie istotnie różnią się od tych, którymi dysponują współcześni naukowcy. Odnosi się to zwłaszcza do starszych kolekcji badawczych, takich jak zbiór dotyczący stylu życia robotników, po czterdziestu latach refleksja nie może być pełna. Co więcej, nawet badacze $z$ lat siedemdziesiątych nie dysponują obecnie własną wiedzą kontekstualną $z$ lat siedemdziesiątych. Niektórzy pamiętają jedynie fragmenty układanki; pewne szczegóły ich wspomnień nawet do siebie nie pasują. Oznacza to, że nie istnieją jedne puzzle. Nie ma jednej układanki z jednym obrazkiem, lecz jest wiele układanek $z$ różnymi obrazkami.

Gdy naukowiec wchodzi w posiadanie tak bogatego materiału i zaczyna go czytać, dotykać, próbuje wyobrazić sobie głosy tych ludzi, których wypowiedzi składają się na czytany tekst, trudno mu powstrzymać się od próby tworzenia wyobrażeń, jak próbowali oni radzić sobie w życiu, jak spędzali swój czas wolny, jakie idee miały na nich wpływ, jak wyglądały ich mieszkania itd. Jednak nawet jeśli my, jako młodzi naukowcy, nie możemy zrozumieć idei, które miały wpływ na to badanie i sprawiły, że było ono możliwe (a przynajmniej zrozumieć ich w taki sposób, w jaki rozumieli je ówcześni badacze), to wydaje się, że możemy zastanowić się nad nimi zarówno w kontekście historycznym, jak i z perspektywy historii i metodologii nauk społecznych. Próbujemy ułożyć puzzle ze wszystkiego, co świadomie i nieświadomie na nas wpływa: danych, sposobu, $\mathrm{w}$ jaki zostały zebrane i w jaki były wówczas interpretowane, wiedzy historycznej, którą posiadamy w danym momencie, naszych własnych tradycji i zwyczajów itd. (Law 2004).

Wydaje się, że istnieje kilka sposobów analizy danych dotyczących stylu życia klasy robotniczej w latach siedemdziesiątych, konsumpcji dóbr kultury w środowisku robotników, ich pracy i sposobu wypoczynku itd. Styl życia robotników obecnie nie jest bynajmniej tematem modnym w węgierskiej socjologii, a badanie ich motywacji do korzystania z dóbr kultury jest jeszcze mniej popularne. Istnieje jednak możliwość przeprowadzenia $\mathrm{w}$ tym zakresie badań porównawczych $\mathrm{w}$ czasie i w przestrzeni (cross-time and cross-national). Ponieważ $\mathrm{w}$ tym samym czasie realizowano podobne badania w innych krajach Europy Wschodniej, można porównać ich wyniki. Na metapoziomie materiał oferuje wiele możliwości przeprowadzenia analizy metodologii badań socjologicznych, jakościowych i ilościowych. Omawiane badania są przykładem mieszanej meto- 
dologii, znacznie mniej popularnej wśród współczesnych socjologów niż jeszcze kilka dekad temu. Celem badania $z$ lat siedemdziesiątych było stworzenie mapy życia danej osoby; podstawą było podejście holistyczne. Zebrany wówczas materiał badawczy — zarówno jego ilość, jak i jakość — jest imponujący $\mathrm{w}$ porównaniu $\mathrm{z}$ badaniami przeprowadzanymi w ostatnich latach. Nie bez znaczenia jest zapewne fakt, że badanie to miało silne podłoże ideologiczne i w związku z tym znaczne poparcie finansowe ze strony partii. Bardzo interesujące byłoby zestawienie owego podłoża ideologicznego $z$ tym, jak badanie było przeprowadzane, jaka jest relacja między materiałem badawczym a tłem ideologicznym w tekstach na nim opartych.

Warto zatem z niekompletnych elementów tworzyć nowe układanki.

Tłumaczenie Anna Woźniak

\section{BIBLIOGRAFIA}

Hammersley Martyn, 1997, Qualitative Data Archiving: Some Reflections on Its Prospects and Problems, „Sociology", t. 31, s. 131-142.

Law John, 2004, After Method: Mess in Social Science Research, Routledge, London.

Mauthner Natasha S., Parry Odette, Backett-Milburn Kathryn, 1998, The Data Are Out There, or Are They? Implications for Archiving and Revisiting Qualitative Data, „Sociology”, t. 32, s. 733-745.

Moore Niamh, 2007, (Re)Using Qualitative Data?, „Sociological Research Online”, t. 12, nr 3 (http://www.socresonline.org.uk/12/3/1.html).

Sági Mária, d.b., Müvelődés és személyiség [Kulturyzacja i osobowość], Népművelési Propaganda Iroda, Budapest.

Szabari Vera, 2005, Krátké dějiny mad’arské sociologie v letech 1948-1989 [Socjologia uprawiana przez socjalistów: krótka historia węgierskiej socjologii w latach 1948-1989], „Sociologicky časopis” / „Czech Sociological Review”, t. 41, s. 659-673.

Szalai Alexander (red.), 1972, The Use of Time: Daily Activities of Urban and Suburban Populations in Twelve Countries, Mouton, The Hague-Paris.

Szántó Miklós, 1967, Életmód, Mưvelődés, Szabadidő [Styl życia, kulturyzacja, wypoczynek], Akadémiai Kiadó, Budapeszt.

Szántó Miklós (red.), 1979, Tanulmányok az életmódról [Studia nad stylem życia], Gondolat, Budapeszt.

Vidovszky Gábor, 1983, „A munkások művelődési motivációinak vizsgálata” [Studium motywacji do kulturyzacji pośród robotników], materiał niepublikowany, dostępny w Voices of the $20^{\text {th }}$ Century Archive.

A PUZZLE OR NOT A PUZZLE?

HUNGARIAN WORKERS' CULTURE COLLECTION OF THE MID-1970S AND A FEW EPISTEMOLOGICAL QUESTIONS

Summary

The text contains information about The Voices of the $20^{\text {th }}$ Century Archive and Research Group, a department created in 2009 in the Institute of Sociology of the Hun- 
garian Academy of Sciences. The archive is a collection of data from historical-and sometimes forgotten-qualitative research. The Group attempts to complete the information and protect it from destruction. For example, in regard to research into labourers' life styles in the 1970s, the author shows how difficult it is after years to create a cohesive whole from the scattered materials. She likens the task to putting together a puzzle. She points to the possible advantages of reusing the material, as well as the limitations a contemporary researcher encounters in attempting to make sense of it.

\section{Key words/słowa kluczowe}

The Voices of the $20^{\text {th }}$ Century Archive; Hungarian sociology / socjologia węgierska; qualitative research / badania jakościowe 